\title{
Steroids: First line treatment in pediatrics
}

\author{
SHELDON SPIER MD FRCPC \\ University of Calgary, Alberta Children's Hospital, Calgary, Alberta
}

\begin{abstract}
S SPIER. Steroids: First line treatment in pediatrics. Can Respir J 1995;2(Suppl A):13A-18A.

The benefits derived from the use of inhaled steroids in pediatric asthma are reviewed in relation to the age of the patient, the delivery system and the compliance versus frequency of administration of these medications. Side effects are discussed with regard to the age of the child and the following systems: the eycs, the skin, the oropharynx, the voice, the immune system, lipid and carbohydrate metibolism, adrenal glands, bone metabolism and growth.
\end{abstract}

Key Words: Asthma, Minuled steroids. Pediumic's

\section{Les stéroïdes : Traitement de première ligne en pédiatrie}

RÉSUMÉ : Les bénéfices dérivés de l'utilisation des stérö̈des en inhalation dans l'asthme pédiatrique selon l'âge, le mode d'administration, et la fidélité au traitement par opposition à la fréquence d'administration de ces médicaments, sont passés en revue. Les effets secondaires sont commentés en ce qui concerne l'âge de l'enfant et les systèmes suivants : yeux, peau, oropharynx, voix, système immunitaire, métabolisme lipidique et glucidique, glandes surrénales, métabolisme osseux et croissance.

\section{$\mathrm{F}$}

OR SEVERAL YEARS YOW INHALATIONAL STEROIDS SUCH - as beclomethasone dipropionate and more recently budesonide have been used to treat childhood asthma. When a new class of drugs is introduced, possible side effects are always a concern. However, with years of clinical experience and publication of better controlled studies, we can now say that inhalational steroids should be used as first line treatment in asthma in the pediatric paticnt. In strong support of this, I quote a section of a recent review article by Barnes and Pedersen (1), "There is now overwhelming evidence that the doses of inhaled steroids required to control asthma in the majority of adults and children are safe and without systemic side effects". The question to pose is: "What is the relationship between benefit and side effects of these medicines?". This review considers benefits according to the age of the child, the delivery system, and the influence of frequency of administration of these medications on compliance. Side ef- lects are discussed with regard to the age of the child and the following systems: the eyes, the skin, the oropharynx, the voice, the immune system, lipid and carbohydrate metabolism ind, above all, adrenal glands, bone metabolism and growth. Before describing these items, one must have a basic understanding of the metabolism and pharmacokinetics of inhaled steroids as well as the delivery system availabic.

\section{INHALED STEROIDS}

The most commonly used inhaled steroids are triamcinolonc, beclomethasone dipropionate, flunisolide, budesonide and, more recently, fluticasone dipropionate (not yet available in Canadil). Beclomethasone dipropionate is the most commonly used inhaled steroid, yet little pharmacokinctic information on the agent is available. Beclomethasone dipropionate is metabolized to beclomethasone mono propionate, which in itself is very active. The half-life of 
budesonide is $2.8 \mathrm{~h}$ in the adult but only $1.7 \mathrm{~h}$ in the child due to a clearance rate that is increased by $50 \%$ in the younger age group (2). Once the medication is absorbed by the digestive system or crosses the bronchial mucosa through inhalation, budesonide is rapidly metabolized, and only $10 \%$ remains in circulation after first passage through the liver. More recently, it has been reported that fluticatsone dipropionate is metabolized even more rapidly and only $1 \%$ remains systemically available after first hepatic passage. This is extremely important for inhalational systems that deposit a large percentage of particles in the digestive system.

Despite the paucity of information on the pharmacokinetics of beclomethasone, we have much more clinical experience with this agent. After adults swallowed (), 2, 4 or $8 \mathrm{mg}$ of budesonide or beclomethasone dipropionate in the evening, the area under the curve of morning serum cortisols is clearly much more affected by beclomethasone than by budesonide (3). Despite the pharmacokinetics of flunisolide and triamcinolone, which are relatively well understood, there have been very lew clinical studies using these two medications. For this reason, we should preferably use beclomethasone and budesonide and, in the near future, fluticasone dipropionate.

Approximately $75 \%$ of budesonide inhaled in the airways is bioavailable. For medications that are bioavailable in the digestive system, deposition in the atiways must be optimized with respect to the digestive systen in order to optimize the benefit:side effect ratio. For medications like fluticasone dipropionate this will probably be much less important. Pulmonary tissue affinities of budesonide are in the same range as beclomethasone dipropionatc/monopropionate and both of these are inferior to the tissue affinity of fluticasone dipropionate. One test used to demonstrate the topical effect of the steroids is their potential to blanche the skin. Studies show that beclomcthasone is inferior to budesonide in this regard while fluticasone dipropionite is about twice as potent as beclomethatsone. In clinical studies. budesonide has been shown to be slightly superior to beclomethasone. Fluticasone seems to be about twice as potent on a milligram basis as beclomethatsone (4.5).

\section{Aerosol delivery systems}

For children, there are three delivery systems to consider: metered dose inhalers with spacer, inspiratory driven dry powder inhalers and wo nebulizers.

Metered dose inhalers: In adding a holding chamber, commonly called a 'spacer', to the metered dosc inhaler, deposition in the gastrointestinal tract is decreased from approximately $70 \%$ to about $10 \%$. At the same time, there is increased pulmonary deposition from approximately 8 to 13 or even $15 \%$ but these latter results are variable $(6,7)$. If an agent like budesonide, which is $10 \%$ bioavailable at the level of the digestive system, is delivered with a metered dose inhaler and $10 \%$ reaches the lungs while $70 \%$ is deposited in the gastrointestinal system, there will be an overall bioavailability from the digestive system of $(0.7 \times 0.1$ to give 0.07 , and from the respiratory system of $0.1 \times 0.710$ give () .07 , resulting in approximately equal bioavailabilities from both. In theory, by adding a holding chamber, onc call almost completely cut the side effects that come from the digestive system. If at the same time the deposition of particles in the airways is dou bled. the side effects and benefits from this area should also double. Thus, the linal result will be a doubling of the efficacy while at the sime time keeping the same level of side effects.

With beclomethasone, which has a larger gastrointestinal biotvailability than budesonide, the use of a spacer should further improve the side effect:benefit ratio for this agent. For fluticasone, this effect would probably be negligible. However, the efficacy per milligram may be doubled, saving considerable expense to the patient in the long term. In young children, there have been very few studies to date, but recontly Bisgaard (8) showed that in using a Nebuhaler with at tight fitting mask, the percentage of the dose that arrives at the face of the child diminishes from $45 \%$ in the three-yearold child to about $20 \%$ in the child under one year old. This is not the case with the 'Babyhaler' which has a volume of $250 \mathrm{~mL}$ and a unidirectional valve that has much less inertia. The percentage of the dose stays the same at $40 \%$ for the older and the young child ( 8 ).

Dry powder inhalers: It has been shown that the size of the particles liberated from dry powder inhaler's varies according to the inspiratory flow up to a certain point. All of these devices have different maximal inspiratory flows for optimal efficacy. To understand the final bioavailability of a chemical product, we should know the particle size and area of deposition according to different inspiratory flows and age of the child. There is little information regarding oral deposition versus inspiratory flow. There are two factors that may go in different directions concerning particle size. The higher the thow, the smaller the particles will be and, thus, the greater the deposition in the airways. As this occurs, we theoretically may increase the impaction on the posterior wall of the pharynx resulting in higher gastrointestinal deposition. Rinsing the mouth after administering budesonide from a Turbuhaler reduces possible side effects by $25 \%$. Recently. Thorsson and Edsbacker (9) demonstrated that using a metered dose inhaler with spacer with budesonide in adults results in a pulmonary deposition of $15 \%$ and a systemic bioavailability of $26 \%$. With the Turbuhaler, the pulmonary deposition doubled to $32 \%$ and the systemic bioavailability increased to just $38 \%$, but whether the patients gargled after inhalations is not clear. Clinically, improved efficacy of the Turbuhaler over the metered dose inhaler with a spacer has been demonstrated for budesonide in prepubertal children in a prospective open study by Pedersen and Agertoft (10). A dose of $0.62 \mathrm{mg}$ administered with a metered dose inhaler with spacer system was less efficacious than $0.45 \mathrm{mg}$ administered by the Turbuhaler as judged by forced expiratory volume in I $s\left(F E V_{I}\right)$ in children after three years of treatment.

Wet nebulization: Data available regarding wel ncbulizaLion are sparse. In placing a liltel between the wet nebulizer and the face, Carlsen Lodrop et al (11) demonstrated that 
19) of the nominal dose was filtered at the face of at 30 -month-old child. compared with $9 \%$ in a four-monthold infant. Approximately $20 \%$ appears to remain constant up to adolescence. Pedersen (10) demonstrated that the proportion that arrives at the fitce of the young child at atly age is approximately 2.5 times more per milligram when the metered dosc inhaler with spacer is used than when the wet nebulizer is uscd. Often, wet nebulization has been described with one type of nebulizer, but numerous types are available in Canada and many are probably very ineffective. The cost of thesi medications per pationt can be high and it is certainly worthwhile to invest even $\$ 50$ to get an excellent nebulizer.

The study by Newman (12) showed that the Hudson Updraft 2 or the Turbo Turrel are very effective. The Acorn or the Pari 360 are less elfuctive especially when a relatively weak air compressor is used such as the De Vilbiss PulmoAid, which is the most conmonly used compressor in Canada. In general, the higher the flow given by the air compressor, the higher the percentage of inhaled particles. A device such as the CR-60) or the De Vilbis AP-50 is capable of delivering $8 \mathrm{~L} / \mathrm{min}$ of air when it is connected to a nebulizer, and this driving flow is much more desirable. However, these devices cost $\$ 400$ to $\$ 500$ compared with $\$ 200$ for the Pulmo-Aid. There is also the cost of the medication itself. Wet nebulization is used primarily for infants under the age of three years old. There have been no pulmoniry deposition studies to date comparing pulmonary versus gastrointestinal deposition of budesonide.

In summary, many nebulizers on the Canadian market are poorly characterized and should not be considered in the treatment of patients. In general. one should use air compressors capable of delivering 6 to $8 \mathrm{~L} / \mathrm{m}$ in when using steroids.

\section{Cost benefit analysis}

When talking about benefits, we should consider socioeconomic advantages. If a wel nebulizer is used, the price of the medication is approximatcly doubled in order to achieve the same benclits as when the metered dose inhaler with spacer is used. The equipment is considerably more expensive as well. In addition, the time of administration of these medications is much quicker with the metered dose inhaler with spacer. Therefore, it the young child or infant is capable of taking the medication with a device that costs half the price and consumes much less time, it should be favoured as a first trial. If onc compares the price of steroids with, for example, nedocromil, using information from adult studies, a dose of $2 \mathrm{mg}$ of nedocromil qid is equivalent to about 300 to 400 $\mu \mathrm{g}$ of budesonide or beclomethasone. This translates to a price of $\$ 4$ for nectocromil for every $\$ 1$ of steroid to achieve the same effect. Finally, steroids are very eflective when administered wice daily, whereas studies with nedocromil or cromolyn are anmost exclusively administered on al yid basis. It is almost impossible to administer medications on al yid basis and very difficult to administer them tid. There are many studies that demonstrate that compliance diminishes with an increase in the frequency of administration.

\section{Effects of age}

Pedersen (10) studied 216 prepubertal children over a three-and-a-half year period. He noted the number of years that children presented with asthma before the introduction of steroids, and classified them into groups as follows: zero to two years, three to four, four to five, or more than five years. The longer the symptoms had been present before the introduction of steroids, the better the patient's FEV 1 on introduction into the study. However, after the follow-up of 3.5 years, it was clear that the earlier budesonide was introduced, the better the final pulmonary function tests were. This study used an open design, but to my knowledge, it is the first sudy that may demonstrate that early anti-inflammatory treatment his long term physiological implications.

There has been much discussion in the literature concerning the benefits of steroids in inhalation in the preschool child and infant. An open study done by Berube ct al (13), one of only two studies done in children under onc year of age, showed an efficacy of hudesonide in wet nebulizttion on symptomatology and pulmonary function testing in inlants aged 0.3 to 0.9 years after three weeks of treatment. A double-blind study by Maayan et al (14) with beclomerhasonc and wel nebulization during two weeks showed an improvement of specific airway resistance, thoracic inctraving, tachypnea and wheezing in infants aged nine months who had recurrently wheezed following an episode of bronchiolitis.

Van Bever et al (15) used a double-blind, crossover study for two periods of one month using $0.5 \mathrm{mg}$ budesonide bid in wet nebulization in infants age 0.3 to 1.5 years. They noted no benefit, but there are several factors that may explatin the poor response, including the carryover effect of a crossover study, a questionable choice of nebulizer and a relatively weak dose of budesonide. Carlsen et al (16) studied beclomethasone with nebulization in children under the age of 1.5 years following an episode of acute bronchiolitis. They showed that the frequency of recurrent wheezing following a six-week treatment was diminished in the treated group.

De Blic et al (17) recently presented a double-blind stuty in 40 infants aged 0.5 to 2.5 years using wot nebulized budesonide I $\mathrm{mg}$ bid delivered with a good atr compressor and nebulizer. There was less use of oral steroids and less wheezing in infants treated with budesonide. Webb et al (18) studied 16 infants in a double-blind crossover fashion and did not record an improvement after two weeks of treatment with wet nebulized beclomethasone. However, three patients had 10 withdraw from the study during the placebo period. In children aged 1.5 to 5.5 years, Storr et al (19) showed a mild eflicacy of wet nebulized beclomethasone.

Bisgaard et al (20) studied 77 infants from the age of one to three years using $0.4 \mathrm{mg}$ budesonide in a metered dose inhaler with spacer and showed a net efficacy in terms of wheeze and diminished number of days on prednisone. This effect seemed to plateau after approximately six to eight weeks, Gleeson and Price (21) studied the effects of budesonide administered with a metered dose inhaler and 
Nebuhaler in children three to five years of age and showed a clear improvement. Ifangovan et al (22) studied 36 children aged 0.9 to five years and showed a clear benefit using wet nebulized budesonide $1 \mathrm{mg}$ bid employing the Hudson 1730 ncbulizer (22). He showed a net improvement in symptomatology while at the same time lowering the number of doses of oral steroids. On average, the administration of $\mathrm{I} \mathrm{mg}$ budesonidc bid resulted in a decrease of $0.5 \mathrm{mg} / \mathrm{kg}$ every two ditys of prednisone after an eight-week period during the double-blind part of the study. After a further eight weeks of treatment in the open part of the study, there was an overall reduction of $1 \mathrm{mg} / \mathrm{kg}$ every two days of prednisone.

Looking at all these studies combined. it is obvious that inhalational steroids are bencficial even under two years of age, but higher doses relative to body weight may have to bc used. This is now better understood with the knowledge that between the age of six months and three years there is a $100 \%$ increase in the quantity of medication deposited on a filter at the child's face using any inhalational technique. To my knowledge, there is no other anti-inflammatory medication that has been clearly proven to be efficacious in children less than two years of age and, more important, less than one year of age.

In older children, Van Essen-Zandvliet et al (2.3) studied the use of $0.6 \mathrm{mg}$ budesonide with a metered dose inhaler with spacer over 22 months and showed a progressive improvement in FEV 1 and symptomatology with an apparent plateauing after two to four months. In addition, they showed a plateauing of daily variability in peak flow after eight months and histamine challenge bronchial reactivity only after 20 months following the start of treatment. Waalkans et al (24) followed this approach and showed that exerciseinduced asthma was improved by treatment with stabilization after two months of inhaled steroids. However, there was only a partial improvement in most of the responders and it was observed in only $50 \%$ of the asthmatics.

These studies show the necessity of continuing the initial treatment of steroids for a period of at least three months in order to establish a level of good health in the child. One approach might be to use approximately twice the dose of inhaled steroids considered appropriate in the long term to achieve rapidly as close to a good state of health as possible. Very often before referral, the child has been sick for several months or years and the entire family has forgotten what it is like for the patient to bc in good health.

\section{SIDE EFFECTS Pulmonary and oral infection}

Recently, attention has focused on varicella and inhalattional steroids. To my knowledge, there has been no calse report in the literature describing a fulminant varicella infection following the sole use of inhalational steroids. I can see no indication for supplementary varicella treatment if doses of topical steroids of $800 \mu \mathrm{g} /$ day or less are used. There may bc some discussion concerning the treatment of children taking doses above $800 \mu \mathrm{g}$ duily. There have been no studies showing reduction in skin thickness in chiliten on inhaled steroids.
Buccal candidiasis is much less frequent in children but I have seen several cases in infants treated with high doses of budesonide in wet suspension. It is important to rinse the mouth well with any liquid after administration of this medication in infants. There have been no cases of cataracts reported with doses of $800 \mu \mathrm{g} /$ day or less in children who had not previously taken systemic steroids for several years. A hoarse voice is rarely described in children.

\section{Metabolic effects}

At a dose of $800 \mu \mathrm{g} / \mathrm{day}$ of budesonide a mild increase in serum high density lipoproteins and an increase in the ratio of serum insulin to glucose has been reported (25). After the dose was lowered to $400 \mu \mathrm{g}$ for four months, this mild difference from baseline disappeared.

Steroids lower the number and activity of ostcoblasts. intestinal absorption of calcium and renal tubular reabsorption of calcium. They increase the number and activity of osteoclasts and increase parathormone in a secondary fashion. However, 0.3 to $0.8 \mathrm{mg}$ of beclomethasone per day had no effect after two years on serum calcium, magnesium, alkaline phosphatase, osteocalcine and urinary calcium and hydroxyproline (26). Doses of $0.2 \mathrm{mg}$ fluticasone dipropionate, budesonide or beclamethasone up to $800 \mu \mathrm{g}$ had no effect on phosphocalcium metabolism $(27,28)$. Beclomethasone $0.6 \mathrm{mg}$ or less in young children between the ages of 0.5 and three years increased the excretion of calcium with an increase in the proportion of urinary calcium to urinary creatinine from 0.07 in normal subjects to 0.24 in treated patients (29). This needs to be further investigated.

Three studies have investigated the effect of steroids on bone density over periods of two, three and 0.5 years at doses of 0.3 to $0.8 \mathrm{mg}$ beclomethasone dipropionate or budesonide and have shown no modification with the DEXA method $(26,30,31)$. There are three studies with $0.4 \mathrm{mg}$ beclomethasone dipropionate showing reduction in serum cortisols, two of which did not use spacers, and the third did not describe the inhalational technique (32-34). The first study by Law (32) established a relationship between the reduction in cortisol and the dose of beclomethasone per square metre surface area of patient. However, this is the only study to date showing this effect. On the other hand, there have been 11 other studies using doses of $0.4 \mathrm{mg}$ or less showing no effect on serum cortisol (35-45). Budesonide at doses of $0.8 \mathrm{mg}$ has showed no modification in serum cortisols $(46,47)$. Howcver, when doses above $0.8 \mathrm{mg}$ beclomethasone or budesonide are administered, reductions vary according to the dose administered (48). In the study by Berube et al (13), there was no significant reduction in serum cortisol among II patients after trettment for three weeks. However, there was a nonsignificant reduction of $20 \%$ in the treated phase and two of the infints had $80 \%$ reductions in serum cortisols.

\section{Effects on growth}

The first studies on growth were very poorly designed and uncontrolled. In addition, they did not take into consideration the fact that poorly controlled asthmat can cause growth 
retardition in the prepubertal child. Once the asthma is treated at the end of puberty, the asthmatic child returns to his or her gencticitly predetermined height. In a recent study (48) $0.8 \mathrm{mg}$ budesonide or beclamethasone showed no evidence in slowing the growth of 58 prepubertal children. In addition. there was no correlation between the growth rate and the dose of inhaled steroid. However, they found that growth varied lo a very important degree with the control of asthma. ie, the poorer the control, the poorer the growth. Doull at at (49) studicd 88 children using $0.4 \mathrm{mg}$ of beclamethasone or placebo using a Diskhaler for seven months and showed a significant and clinically important growth retardation. This is possibly the only study that follows growth using the Diskhaler and the only one showing growth retardation using this dose of beclomethasone. Three studies show that there is no effect on growth using budesonide 0.2 to $0.7 \mathrm{mg}$ over a period of two to 3.5 years. One of these studics is well designed and double-blind, the other two being onen but controlled $(10,50,51)$. The study by Varsano et al (5I) included young children from the age of 3.5 to seven years (51). One dose of 0.5 to $1 \mathrm{mg}$ of fluticasone dipropionate over a period of one year in an open, controlked study showed no modilication of growth (52). There was no change after $0.2 \mathrm{mg}$ budesonide on biochemical parameters such as somatomedin-I (IGF-1), IGF-binding protein-3, the carboxy terminal propetide of type 1 procollagen (PICP) and the amino-terminal propeptide of type III procollagen (PIIINP). At $0.8 \mathrm{mg}$, there Wals a discrete reduction in the level of PIIINP, the clinical importance of which is uncertain (53).

Knemometry is an extremcly scmsitive technique for studying lower leg length growth over it short time. First, compared with the placebo, there has been a net reduction in growth when a daily dose of prednisone of $2.5 \mathrm{or} 5 \mathrm{mg}$ is used (54). With 0.2 to $0.4 \mathrm{mg}$ of budesonide in a metered dose inhaler with spacer, there was no significant change compared with placebo; however, there was a mild change when the dose was $0.8 \mathrm{mg}(55,56)$. This difference is fill less than the effect of using $2.5 \mathrm{mg}$ of prednisone. A dose of $0.2 \mathrm{mg}$ fluticasone showed a reduclion approximately eyuvalent to that obtained with a dose of $0.4100 .8 \mathrm{mg}$ budesonide (54-56). A dose of 0.4 to $0.8 \mathrm{mg}$ beclomethasone taken wilh a Disk-

\section{REFERENCES}

I. Barnes PJ. Pedersen S. Effrcacy and safety of inhaled corticosteroids in asthma. Am Rev Respir Dis 1993:148:S1-S26.

2. Pedersen S. Steffensen G, Ekman I, Tonnesson M, Borga O.

Pharmacokinetics of budesonide in children with asthma. Eur I ('lis Plarmacol 1987:31:579-82.

3. Johansson SA. Andersson KE. Brattsand R. Gruvstad E. Hedner P. Topical and systemic glucocorticoid polencies of budesonide and beclomethasone dipropionate in man. Eur J Clin Pharmacol 1982:22:523-9.

4. Johansson AS, Andersson KA. Brattsand R, Gruvstad E. Hedner P. Topical and systemic glucocorticoid potencies of budesonide, beclomethasone dipropionate and prednisolone in man. Eur Respir J 1982:122 (Suppl):74-82.

$\therefore$ Phillips GH. Structure-activity relationship of topically active steroids: the selection of fluticasone propionate. Respir Med 1990;84(Suppl A):19-23.

6. Newman SP, Pavia D. Moren F, Sheahan NF, Clarke SW. Deposition of pressurized aerosols in the human respiratory fracts. Thorax $1981: 36: 52-5$

Newman SP. Moren G. Pavia D, Little F, Clarke SW. Deposition of

pressurized suspension acrosols inhaled through extension devices. Am Rev Respir Dis 1981:124:317-20

8. Bisgaard H. Dose of aerosol inhaled by young children from a small-volume spacer (Babyspatcer). Eur J Respir Dis 1993;6( Suppl):352S. haler showed a marked reduction in lower leg length growth almost equivalent to that of taking 2.5 or $5 \mathrm{mg}$ prednisone $(54,57)$. I have noted total arrest of growth only using beclomethasone in Diskhaler form in doses of $0.6 \mathrm{mg}$ in 1 wo prepubertal brothers with cystic fibrosis and atsthma, and in one intant using wet nebulized budesonide at doses approaching $4 \mathrm{mg}$ per day. We should keep in mind that bioavailahility of beclomethasone through the gastrointestinal tract is morc inportant than that of budesonide or fluticasone.

\section{CONCLUSION}

A dose of $0.4 \mathrm{mg}$ or less of budesonide or beclomethasone, taken with the proper inhalational device, gives enormous benefits to patients, with negligible side effects. A dose of 0.4 to $0.8 \mathrm{mg}$ is strong enough that there is basically no competition from other anti-inflammatory medications with regard to benefits and gives very few, probably clinically unimportant, side effects. Patients normally requiring over $0.8 \mathrm{mg}$ of these medications would probably he hospitalized on many occasions if it were not for the medications availability, or be receiving systemic steroids with many more side effects in order to control their asthma. However, one must survey the side effects more closely in this group.

For children aged five years and older, it is evident that inhalational steroids should be the treatment of first choice in long term control of asthma. Although more studies need to be done regarding the benefit to side effect ratio in children under the age of five years, steroids are probably the treatment of first choice even in the preschool child and infant. No other anti-inflammatory medication has been proven to be effective in children less than two years of age.

Compliance must always be considered when prescribing treatments. This puts the metered dose inhaler with spacer in front of the wet nebulizer in terms of cost, convenience and acceptability. In addition, there is the advantage of using inhaled steroids on a bid basis rather than a tid or qid basis as with other anti-inflammatory medications. In Canada, better standardization of devices delivering products to the respiratory system must be assured in the future. For any new device that comes on the market, benefits must be compared with side effects for all medications that are being delivered with it.

9. Thorsson L, Edsbacker $\mathrm{S}$. Lung deposition of budesonide from Turbuhaler is twice that from a pressurized melered dose inhaler (MDI). Thorax 1993:48:434.

I0. Agertoft L. Pedersen S. Effects of long-term treatment with an mhaled corticosteroid on growth and pulmonary function in asthmatic children Respir Med 1994:88:373-81.

I I. Carlsen Lodrup KC. Nikander K. Carlsen KII. How much nebulized budesonide reaches infants and toddlers? Arch Dis Child 1992:67:1077-9.

12. Newman S. Nebulization of budesonide suspension. In: Godfrey S. el al. Budesonide Nebulizing Suspension: Zurich Workshop Report. Oxtord: Oxford Clinical Communications, 1989:1!-6.

1:. Berube D. Spier S. Lapierre JG. Marcotte JE. Lamarre A. Effects of budesonide in infantile asthma. Am Rev Respir Dis 1990;141:A905.

It. Maayan C. Itzhaki T. Bar-Yishay E. Gross S. Tal A. Gofrey S. The functional response of infants with persistent wheezing to nebulized beclomethasone dipropionate. Pediatr Pulmonol 1986:2:9-I4.

IS. Van Bever HP. Schuddinck L. Wojciechwski M. Stevens WJ. Aerosolized budesonide in asthmatic infants: a double blind study. Pediatr Pulmonol I990:9:177-80.

10. Carlsen K.H. Leegard J, larsen S. Orstavik I. Nebulized beclomethasone dipropionate in recurrent obstructive episodes after acute bronchiolitis. Arch 
Dis Child 1988:63:1428-33

17. de Blic J. Delacourt C. Le Bourgeois M. Hahut B. Allouche J, Scheinmann P. A double blind parallel group study of nebulized budesonide in severe infantile asthma. Am Rev Respir Dis 1993; 147:A266.

18. Webb MSC. Milner AD, Hiller E.I, Henry RL. Nebulized beclomethasone dipropionate suspension. Arch Dis Child 1986;61:1108-10.

19. Storr J, Lenney CA, Lenney W. Nebulized beclomethasone dipropionate in preschool asthma. Arch Dis Child 1986:61:270-3.

20. Bisgaard II, Munck SL, Nielsen JP, Petersen W, Ohlsson SV. Inhaled budesonide for treatment of recurrent wheering in early childhood. Lancet 1990:336:649-51

21. Gleeson JGA, Price JF. Controlled trial of budesonide given by the Nebuhaler in preschool children with asthma. BMJ 1988:297: 163-6.

22. Ilangovan P, Pedersen S. Godfrey S, Nikander K, Noviski N, Warner JO Treatment of severe steroid dependent preschool asthma with nebulized budesonide suspension. Arch Dis Child I993;68:356-9.

23. Van Essen-Zandvliet EEM. Hugues MD, Waalkens HJ, et al. Effects of 22 months treatment with inhaled corticosteroid and/or beta 2-agonist on lung function, airway responsiveness and symptoms in children with asthma. Am Rev Respir Dis 1992:146:547-54.

27. Waalkens HJ, van Essen-Zandvliet. Gerritsen J, et al. The effect of an inhaled corticosteroid (budesonide j on exercise-induced asthma in children. Eur Respir J 1993:6:652-6.

25. Turpeinen M, Sorva R, Juntunen-Backman K. Changes in carbohydrate and lipid metabolism in children with asthma inhaling budesonide. J Allergy Clin Immunol 1991:88:384-9.

26. Konig P. Hillman L. Cervantes C. el al. Bone metabolism in childich with asthma treated with inhaled beclomethasone dipropionate. J Pediatr 1993; 122:219-26

27. Wolthers OD, Pedersen S. Bone turnover in asthmatic children treated with oral prednisolone or inhaled budesonide. Pediatr Pulmonol 1993:16:341-6.

28. Wolthers OD, Karpessen-Nielsen H. Pedersen S. Bone turnover in children with asthma treated with inhaled fluticasone propionate and beclomethasone dipropionate. Paediatr Respir Dis. (In press)

29. Bentur L. Bibi H, Rubin AE, Bentur Y. Inhaled corticosteroids in young children: association with hypercalciuria. Am Rev Respir Dis [993:147:A265

31). Agertoft L, Pedersen S. Bone densitometry in children treated for 3-6 years with high dose inhaled budesonide. Eur J Respir Dis 1993;6:26IS.

31. Baraldi E, Bollini MC. De Marchi AM, Guglielmi A, Zacchello F. Elfect of beclomethasone (BDP) on bone mineral content assessed by dual energy X-ray absorptiometry in asthmatic children. Eur J Respir Dis 1993;6:26IS

32. Law CM, Marchant JL. Honour JW, Preece MA. Warner JO. Nocturnal adrenal suppression in asthmatic children taking inhaled beclomethasone dipropionate. Lancet 1986:i:942-4.

3. Tabachnik E. Zadik Z. Diumal cortisol secretion during therapy with inhaled beclomethasone dipropionate in children with asthma. J Pediar 1991:120:294-6.

3t. Philip M, Aviram M, Leiberman E, et al. Integrated plasma cortisol concentration in children with asthma receiving long-term inhaled corticosteroids. Pediatr Pulmonol 1992:12:84-9.

35. Priftis K. Milner AD. Conway E, Honour JW. Adrenal function in asibmat. Arch Dis Child 1990:65:838-40

36. Katsunuma T. Akasawa A. Iikura Y. Adrenal function of children with bronchial asthma treated with beclomethasone dipropionate. Ann Allergy 1992:69:529-32.
37. Meltzer EO. Kemp JP. Welch MJ, Orgel HA. Effect of dosing schedule on efficacy of beclomethasone dipropionate aerosol in chronic asthma. Am Rev Respir Dis 1985:131:732-6.

3i. Feigang B, Asthford DR. Adrenal cortical function after long-term beclomethasone aerosol therapy in early childhood. Ann Allergy 1990:64:342.

34). Godfrey S, Konig P. Beclomethasone aerosol in childhood asthma. Arch Dis Child 1973:48:665-70

4). Dickson W, Hall CA. Ellis M. Horrocks RH. Beclomethasone dipropionate aerosol in childhood asthma. Arch Dis Child 1973;48:671-5.

HI. Klein R, Waldman R, Kershnar H, et al. Treatment of chronic childhood asthma: I. A double-blind crossover trial in nonsteroid-dependent patients. Pediatrics 1977:60:7-13.

42. Godfrey S, Konig P. Treatment of childhood asthma for 13 months and longer with beclomethasone dipropionate aerosol. Arch Dis Child 1974:49:591-6.

4. Goldstein DE, Konig P. Effect of inhaled beclomethasone dipropionate on hypothalamic-pituitary-adrenal axis function in children with asthma. Pediatrics 1993;72:60-4.

4t. Kat/ RM, Rachelefsky GS, Segel SC, Spector SL, Rhor AS. Twice daily beclomethasone dipropionate in the treatment of childhood asthma. J Asthma 1986;23:1-7.

45. Bisgaard H. Pedersen S, Damkjaer Nielsen M. Osterballe O. Adrenal function in asthmatic children treated with inhaled budesonide. Acta Pacdriatr Scand 1991:80:213-7.

if . Bisgaard H. Damkjaer Nielsen M, Andersen B, et al. Adrenal function with bronchial asthma treated with beclomethasone dipropionate or budesonide. J Allergy Clin Immunol 1988;81:1088-95

47. Ninan TK, Reid IW, Carter PE, Smail PJ, Russel G. Adrenal function in children with severe persistent asthma. Thorax 1993:48:599-602.

4R. Ninan TK, Russel G. Asthma, inhaled corticosteroid treatment, and glow th. Arch Dis Child 1992;67:703-5.

49. Doull IJM. Freezer NJ, Holgate ST. Growth of asthmatic children un inhaled corticosteroids. Am Rev Respir Dis 1993;147:A265.

50). Merkus P, van Essen-Zandvliet E. Duiverman EJ, et al. Long-term effect of inhaled corticosteroids on growth rate in adolescents with asthma. Pediatrics 1993:91:1121-6.

51. Varsano I, Volovitz B. Malik H. Amir Y. Safety of 1 year of treatment with budesonide in young children with asthma. J Allergy CTin Immunol 1990:85:9[4-20.

52. Bourgeois M. Benoist MR de Blic J Allaire JM. Scheinmann P. One year treatment with two doses of inhaled flunisolide (250 and $500 \mathrm{mcg}$ BID): effects on growth of asthmatic children. Am Rev Respir Dis 1993;147:A265

53. Wolthers OD, Juul A, Hansen M. Muller J, Pedersen S. Growth markers in asthmatic children treated with inhaled budesonide. Eur J Respir Dis 1993;6:26IS

5. Wolthers OD, Pedersen S. Controlled study of linear growth in asthmatic children during treatment with inhaled glucocorticosteroids. Pediatrics $1992 \cdot 89 \cdot 839-42$

55 . Wolthers OD, Pedersen S. Short term linear growth in asthmatic children during treatment with prednisolone. BMJ 1990:301:145-8.

56. Wolthers OD, Pedersen S. Growth of asthmatic children during treatment with budesonide: a double blind trial. BMJ 1991;303:163-5.

57. Wolthers O, Pedersen S. Short term growth during treatment with inhaled thuticasone dipropionate and beclomethasone dipropionate. Arch Dis Child 1993:68:673-6. 


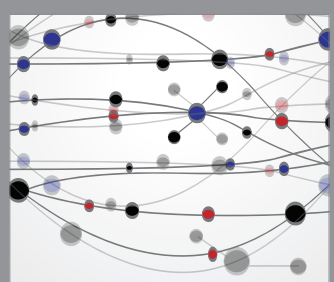

The Scientific World Journal
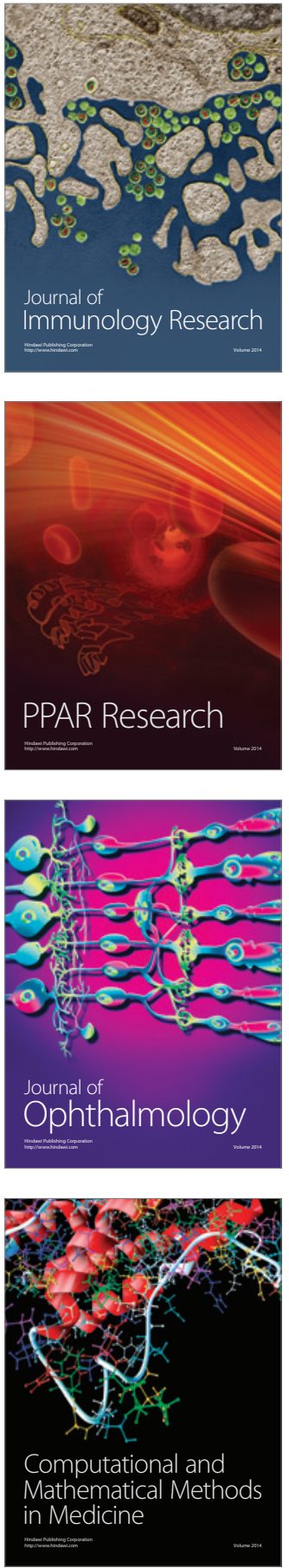

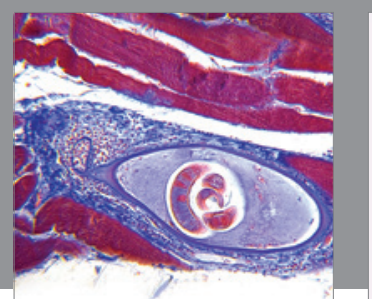

Gastroenterology Research and Practice

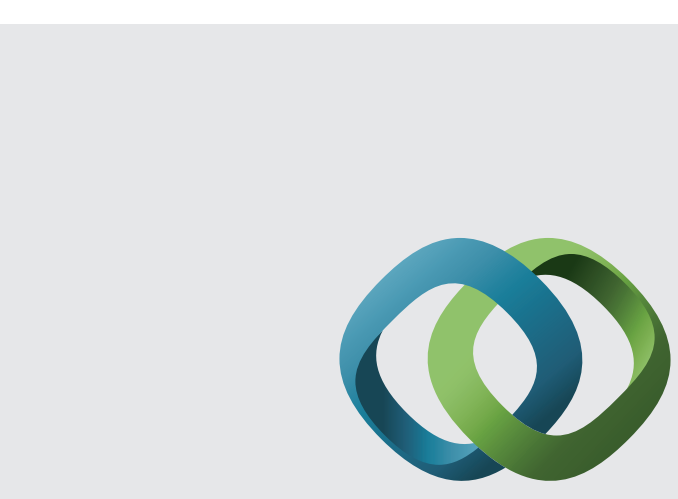

\section{Hindawi}

Submit your manuscripts at

http://www.hindawi.com
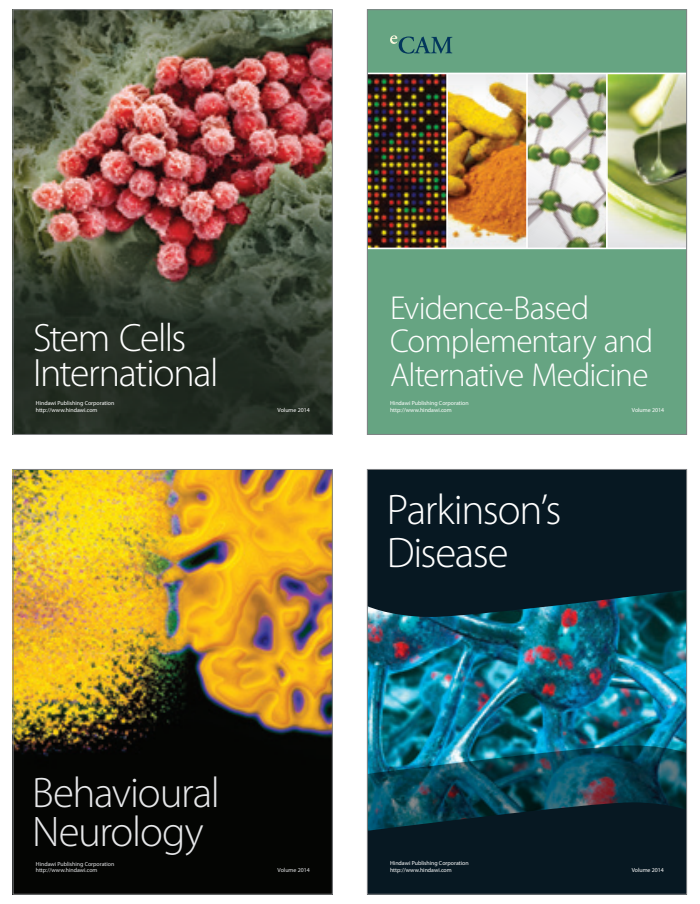
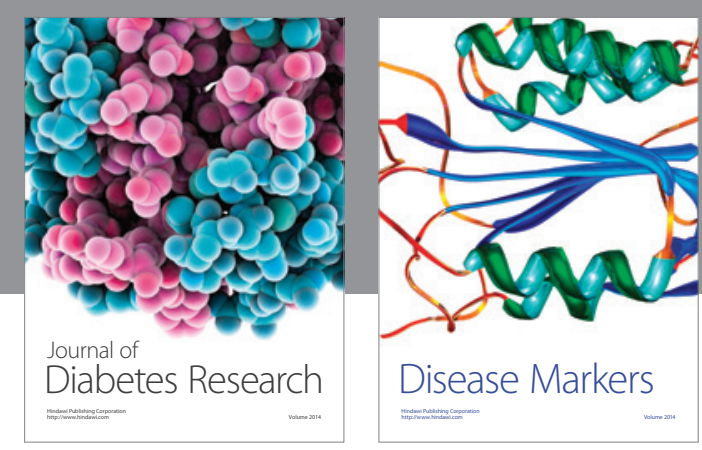

Disease Markers
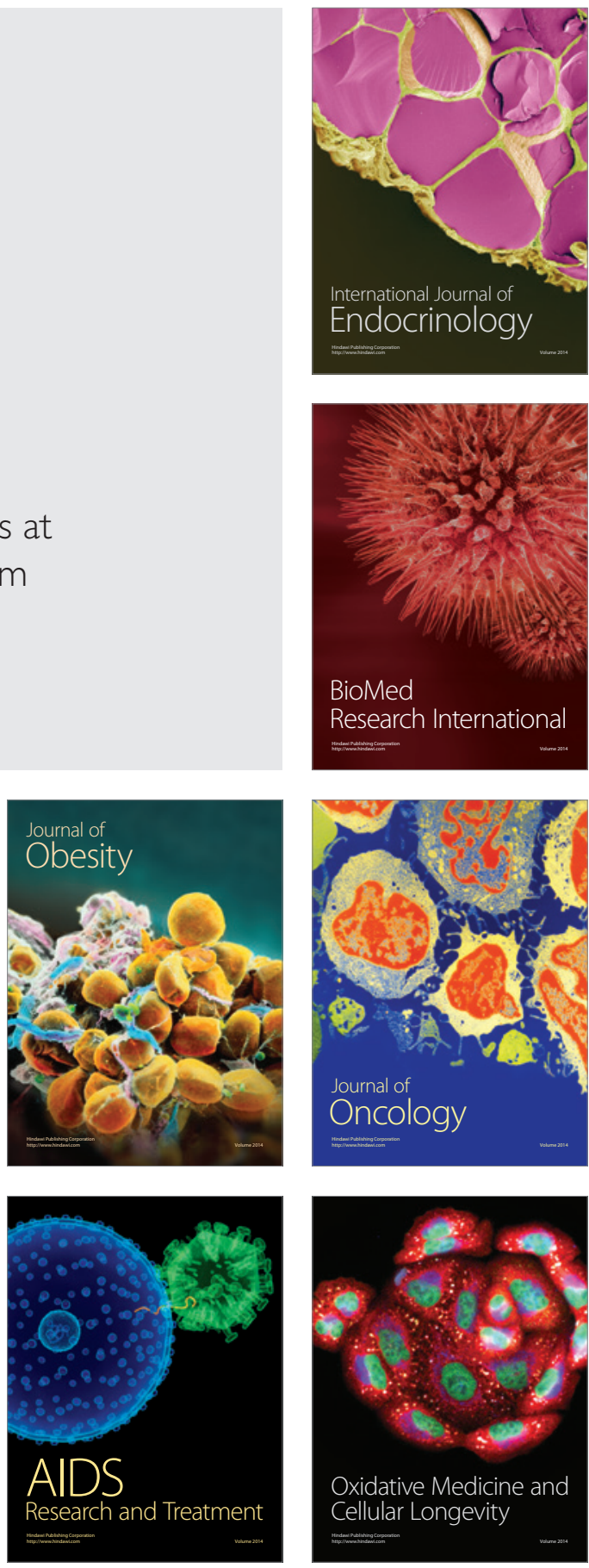